\title{
Importance of waterborne cadmium and zinc accumulation in the suspension-feeding amphioxus Branchiostoma belcheri
}

\author{
Bin $\mathrm{Lu}^{1}$, Caihuan $\mathrm{Ke}^{1}$, Wen-Xiong Wang ${ }^{2, *}$ \\ ${ }^{1}$ State Key Laboratory for Marine Environmental Science, College of Oceanography and Environmental Science, \\ Xiamen University, Xiamen 361005, PR China \\ ${ }^{2}$ Division of Life Science, The Hong Kong University of Science and Technology, Clear Water Bay, Kowloon, \\ Hong Kong SAR
}

\begin{abstract}
The amphioxus is often used as a model marine animal in biological research because of its special position in evolution. These animals have transparent surfaces and nonrespiratory gills, and whether such specialization plays a role in the accumulation of metals remains unknown. In the present study, we determined the biokinetics of $\mathrm{Cd}$ and $\mathrm{Zn}$ in the amphioxus Branchiostoma belcheri, including metal assimilation efficiency (AE), the dissolved Cd and $\mathrm{Zn}$ uptake rate constants, and the efflux rate constant. Metal AEs were 7.6 to $34.3 \%$ for $\mathrm{Cd}$ and 8.4 to $42.9 \%$ for $\mathrm{Zn}$ in amphioxus feeding on 5 different algae, and the AEs of $\mathrm{Zn}$ were significantly influenced by the algal concentration. The dissolved uptake rate constants were $0.107 \mathrm{~g}^{-1}$ $\mathrm{d}^{-1}$ for $\mathrm{Cd}$ and $0.061 \mathrm{~g}^{-1} \mathrm{~d}^{-1}$ for $\mathrm{Zn}$. The efflux rate constants were 0.012 to $0.033 \mathrm{~d}^{-1}$ for $\mathrm{Cd}$ and 0.031 to $0.040 \mathrm{~d}^{-1}$ for $\mathrm{Zn}$ following dietary or waterborne metal exposure. Overall, these determined biokinetics were comparable to those found in other suspension feeders, such as marine bivalves. However, amphioxus had a higher absorption efficiency from the dissolved phase than those found for marine bivalves, largely caused by the unique surface sorption of metals. Such unique surface uptake contributed to the dominance of waterborne $\mathrm{Cd}$ accumulation in amphioxus under most environmental conditions. For $\mathrm{Zn}$, dietary exposure appeared to be more important than aqueous uptake due to its relatively high particle reactivity. The predicted trophic transfer factors of $\mathrm{Cd}$ and $\mathrm{Zn}$ were $<1$ under most conditions.
\end{abstract}

KEY WORDS: Amphioxus $\cdot$ Metals $\cdot$ Bioaccumulation $\cdot$ Exposure $\cdot$ Pathway

\section{INTRODUCTION}

Amphioxus is the only existing group of animals belonging to the subphylum Cephalochordata and is a very unique group of suspension feeders. Its members have a dorsal and hollow nerve cord, segmental muscles, and a post-anal tail similar to vertebrates. Due to its special position in the evolutionary tree, amphioxus has been used as a model organism in many developmental and evolutionary studies (Holland et al. 2004). Amphioxus is distributed in habitable sandy beaches of temperate and shallow coastal waters around the world. Branchiostoma belcheri (also known as lancelet) lives in the sandy sediment of the southern China Sea and is commonly found in the Xiamen area (Light 1923), and can be easily identified under the microscope (Zhang et al. 2006).

A benthic and obligate filter feeder, amphioxus have a pellucid surface and non-respiratory gills which are very different from those in fish. Gills are the primary organs of aquatic respiration in the majority of fish species, and are important sites for osmoregulation, acid-base regulation, and excretion 
of nitrogenous wastes (Evans et al. 2005). In contrast to other aquatic animals, amphioxus gills are made up of numerous vertically oriented branchial baskets containing an internally supported rod, blood vessels, and neurons, and are not the main respiratory organs. Externally they possess a ciliated epithelium (Evans et al. 2005). Although the branchial blood vessels link the ventral aorta to the dorsal aorta, the gill bars of amphioxus have a small oxygen-diffusing capacity and are not a likely site of respiratory gas exchange. Schmitz et al. (2000) reported that the gill bars of amphioxus have only $1 \%$ capacity as a respiratory organ, and the surface of coelomic cavities and muscles may function in respiration. Instead, amphioxus use the gill bars to filter food particles from water. They can efficiently filter a wide variety of foods ranging from microplankton to colloidal particles through the branchial basket (Ruppert et al. 2000, Nielsen et al. 2007, Chen et al. 2008).

Given their ability to retain particles and to absorb chemicals through their body surface, one question to be addressed is whether amphioxus have routes of metal accumulation different to other suspension feeders, such as marine bivalves. Over the past few decades, extensive studies have been done on metal bioaccumulation and biokinetics in different groups of marine organisms, including suspension feeders and deposit feeders (for reviews, see Wang \& Rainbow 2008, Wang 2011). Dietary accumulation is often the dominant route for metal bioaccumulation in marine animals (Wang \& Fisher 1999, Wang 2011). To our knowledge, no study has to date examined the exposure and bioaccumulation of metals in amphioxus. Previous limited ecotoxicological studies on amphioxus only focused on the acute toxicity of metals (Wu et al. 1999, Bhattacharya et al. 2008) and the energy transfer in amphioxus (Nash et al. 2009).

Cadmium $(\mathrm{Cd})$ is an environmental stressor due to its toxicity, persistence and accumulation. Zinc (Zn) is an essential metal, playing an important role in metalloenzymes. Both $\mathrm{Cd}$ and $\mathrm{Zn}$ are the common toxic metals in many polluted environments. In the present study, we quantified the biokinetics and possible biomagnification of $\mathrm{Cd}$ and $\mathrm{Zn}$ in the amphioxus Branchiostoma belcheri. The parameters considered in this study included the dissolved uptake rate of $\mathrm{Cd}$ and $\mathrm{Zn}$, the assimilation efficiency (AE) of metals ingested from different foods (3 diatoms: Thalassiosira pseudonana, Skeletonema costatum, and Chaetoceros gracilis; 1 green alga: Chlorella autotrophica; and 1 prymnesiophyte: Isochrysis galbana), and the efflux rate constant following dietary and waterborne exposure. To quantify these parameters, we employed the gamma radioactive isotopes ${ }^{109} \mathrm{Cd}$ and ${ }^{65} \mathrm{Zn}$ to trace the behavior of these metals in the amphioxus. Based on these kinetic measurements, we subsequently modeled the contribution of different uptake routes (waterborne vs. dietary) and the potential biomagnification of $\mathrm{Cd}$ and $\mathrm{Zn}$ in amphioxus. We employed the kinetic modeling approach, which has been validated in many aquatic animals over the past few decades (Wang \& Rainbow 2008).

\section{MATERIALS AND METHODS}

\section{Animals and radioisotopes}

Amphioxus Branchiostoma belcheri (35 to $45 \mathrm{~mm}$ in body length) were collected from the coastal waters of Xiamen, Fujian, China in May 2010. The animals were transported to the laboratory in aerated containers filled with seawater (salinity: 30 ) and 2.5 to $5 \mathrm{~cm}$ of sand, and then cultured in a $40 \mathrm{l}$ aerated container at $20^{\circ} \mathrm{C}$ for about $4 \mathrm{wk}$ and fed a live algal diet. All individuals were examined for overall health (e.g. physical damage, full gut, and normal swimming) and were morphologically identified. Prior to the radioactive feeding experiments, the amphioxus were continuously fed the same algal diets for 2 to $3 \mathrm{~d}$.

We used the radioisotopes ${ }^{109} \mathrm{Cd}$ and ${ }^{65} \mathrm{Zn}$ as the radiotracers to trace the kinetics of $\mathrm{Cd}$ and $\mathrm{Zn}$, respectively. ${ }^{109} \mathrm{Cd}$ (as $\mathrm{CdCl}_{2}$ in $0.1 \mathrm{M} \mathrm{HCl}^{\text {, specific }}$ activity: $0.12 \mu \mathrm{mol} \mathrm{MBq}^{-1}$ ) and ${ }^{65} \mathrm{Zn}$ (as $\mathrm{ZnCl}_{2}$ in

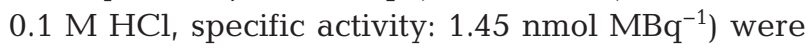
obtained from Eckert \& Ziegler Isotope Products. The stable $\mathrm{Cd}$ and $\mathrm{Zn}$ used for the dissolved uptake experiments were $\mathrm{CdCl}_{2}$ and $\mathrm{ZnCl}_{2}$ standard solutions $\left(1 \mathrm{mg} \mathrm{ml}^{-1}\right.$, from Perkin-Elmer Pure Atomic Spectroscopy) in $2 \% \mathrm{HNO}_{3}$.

\section{Waterborne uptake of $\mathrm{Cd}$ and $\mathrm{Zn}$}

We traced the uptake of $\mathrm{Cd}$ and $\mathrm{Zn}$ in the animals over a short exposure period at different metal concentrations. The tested total $\mathrm{Cd}$ concentrations were $0.2,1,5,20$, and $86 \mu^{-1}$, and the $\mathrm{Zn}$ concentrations were $2,8,40,100$, and $170 \mu \mathrm{g} \mathrm{l}^{-1}$, with additions of trace amounts of $14.9 \mathrm{kBq} \mathrm{l}^{-1}{ }^{109} \mathrm{Cd}$ (equivalent to $0.2 \mathrm{\mu g} \mathrm{l}^{-1}$ ) and $88.8 \mathrm{kBq}^{-1}{ }^{65} \mathrm{Zn}$ (equivalent to $8 \mathrm{ng}$ $\left.\mathrm{l}^{-1}\right)$, respectively, in $100 \mathrm{ml}$ of $0.22 \mu \mathrm{m}$ filtered seawater. The exposure solutions contained both the radioisotopes and the stable metals, except the lowest $\mathrm{Cd}$ concentration treatment. There were 6 replicated beakers, each containing 1 individual am- 
phioxus, for each treatment. At $0.5,3,6$, and $9 \mathrm{~h}$, the amphioxus were removed and rinsed with nonradioactive filtered seawater. The radioactivity was counted for $1 \mathrm{~min}$, and afterwards the amphioxus were returned to the exposure medium immediately. At $9 \mathrm{~h}$, the radioactivity was measured and the amphioxus were dried at $80^{\circ} \mathrm{C}$ to constant weights to determine dry weight. We also sampled $1 \mathrm{ml}$ water at each time point and measured its radioactivity in the exposure medium. The radioactivity in the medium decreased by $<5 \%$ over the $9 \mathrm{~h}$ exposure period, thus the metal concentrations in the seawater were relatively constant.

The newly accumulated metal concentrations were calculated from the radioactivity detected in the animals and the specific activity of the radioisotopes. The influx rate $\left(I, \mu \mathrm{g} \mathrm{g}^{-1} \mathrm{~h}^{-1}\right)$ was then calculated from the slope of the linear regression between the newly accumulated metal concentration in amphioxus and the exposure time. Finally, the uptake rate constant from the water $\left(k_{\mathrm{u}}, \mathrm{lg}^{-1} \mathrm{~d}^{-1}\right)$ was calculated from the slope of the linear regression between the influx rate and the metal concentration in the medium.

\section{Dietary assimilation of Cd and Zn}

We quantified the dietary AEs (\%) of amphioxus fed 5 different types of algae (3 diatoms: Thalassiosira pseudonana, Skeletonema costatum, and Chaetoceros gracilis; 1 green alga: Chlorella autotrophica; and 1 prymnesiophyte: Isochrysis galbana) at one concentration, and 1 diatom diet (T. pseudonana) at different concentrations (food concentration experiment). The 5 algal species were radiolabeled with ${ }^{109} \mathrm{Cd}$ and ${ }^{65} \mathrm{Zn}$ as described in Wang \& Fisher (1996). After 4 to $5 \mathrm{~d}$ of growth and radiolabeling, algae were filtered from their radiolabeling culture, and resuspended twice in filtered seawater to remove the unradiolabeled metals. Radiolabeled food particles were then added to $600 \mathrm{ml}$ of filtered seawater in a 11 polypropylene beaker, at a concentration of $10^{5}$ cells $\mathrm{ml}^{-1}$ for each species. In the food concentration experiment, the radiolabeled diatom concentrations were $5 \times 10^{3}, 2 \times 10^{4}, 1 \times 10^{5}$, and $5 \times 10^{5} \mathrm{cells} \mathrm{m}^{-1}$ for T. pseudonana. Amphioxus previously fed the same type of algae for 2 to $3 \mathrm{~d}$ were placed individually into each beaker and fed on this food suspension for 40 min, which was shorter than the gut passage time of food materials. Each experimental group contained 6 replicated individuals. After 40 min of pulse feeding, the amphioxus were rinsed with filtered seawater and the radioactivity of each individual am- phioxus was counted for $1 \mathrm{~min}$. They were then placed in another beaker with $100 \mathrm{ml}$ filtered seawater containing the same type of nonradioactive food suspension, allowing them to depurate the ingested radioactive food. The radioactivity of each amphioxus was monitored every 2 to $4 \mathrm{~h}$. AE was calculated as the percentage of metals remaining in the amphioxus after $20 \mathrm{~h}$ of depuration.

\section{Efflux of $\mathrm{Cd}$ and $\mathrm{Zn}$ following waterborne and dietary exposure}

$\mathrm{Cd}$ and Zn elimination from amphioxus was quantified following waterborne and dietary exposure. The amphioxus were exposed to waterborne or dietary $\mathrm{Cd}$ and $\mathrm{Zn}$ for $7 \mathrm{~d}$ to accumulate the metals, and were then depurated for 1 mo to determine the elimination of metals. For waterborne exposure, 10 amphioxus were kept in 21 filtered seawater containing $37 \mathrm{kBq} \mathrm{l} \mathrm{l}^{-1}$ of ${ }^{109} \mathrm{Cd}$ and $37 \mathrm{kBq} \mathrm{l}{ }^{-1}$ of ${ }^{65} \mathrm{Zn}$ for $7 \mathrm{~d}$. Each day, the animals were removed from their exposure medium and fed on diatom food Thalassiosira pseudonana for $2 \mathrm{~h}$. For dietary exposure, 10 amphioxus were fed with radiolabeled algae for $2 \mathrm{~h}$ each day in 21 seawater. They were then returned to nonradioactive seawater for the remaining $22 \mathrm{~h}$ of the day. Both waterborne and dietary exposure regimes lasted for $7 \mathrm{~d}$, and the seawater was renewed daily. After $7 \mathrm{~d}$ of radiolabeling, the amphioxus were rinsed with seawater and their radioactivity was counted immediately. Each individual was then kept in $100 \mathrm{ml}$ nonradioactive seawater (renewed daily) for $1 \mathrm{mo}$, and fed fresh algae daily. Radioactivity in the amphioxus was measured every $2 \mathrm{~d}$. A linear regression between the natural log of the percentage of retained ${ }^{109} \mathrm{Cd}$ and ${ }^{65} \mathrm{Zn}$ and the depuration period was conducted, and the slope of the slower exchanging compartment ( 5 to $31 \mathrm{~d}$; for $\mathrm{Zn}$ after waterborne exposure: 10 to $31 \mathrm{~d}$ ) was the efflux rate constant $\left(k_{\mathrm{e}}\right)$.

\section{Kinetic modeling}

Under steady-state conditions, $\mathrm{Cd}$ and $\mathrm{Zn}$ accumulation in amphioxus can be calculated using the following equations (Thomann 1981, Wang \& Fisher 1997):

$$
\begin{gathered}
C_{\mathrm{ss}}=C_{\mathrm{ss}, \mathrm{w}}+C_{\mathrm{ss}, \mathrm{f}} \\
C_{\mathrm{ss}, \mathrm{w}}=k_{\mathrm{u}} \times C_{\mathrm{w}} / k_{\mathrm{ew}} \\
C_{\mathrm{ss}, \mathrm{f}}=\mathrm{AE} \times \mathrm{IR} \times C_{\mathrm{f}} / k_{\mathrm{ef}}
\end{gathered}
$$


where $C_{\mathrm{ss}}$ is the total metal concentration in the amphioxus $\left(\mu \mathrm{g} \mathrm{g}^{-1}\right), C_{\mathrm{sS}, \mathrm{w}}$ is the metal concentration due to waterborne exposure, $C_{\mathrm{ss}, \mathrm{f}}$ is the metal concentration due to dietary exposure, $k_{\mathrm{u}}$ is the uptake rate constant from the dissolved phase $\left(\mathrm{l} \mathrm{g}^{-1} \mathrm{~d}^{-1}\right)$, $C_{\mathrm{w}}$ is the metal concentration in the dissolved phase $\left(\mu \mathrm{g} \mathrm{l}^{-1}\right), k_{\mathrm{ew}}$ is the efflux rate constant following uptake from the dissolved phase $\left(\mathrm{d}^{-1}\right)$, IR is the ingestion rate $\left(\mathrm{g} \mathrm{g}^{-1} \mathrm{~d}^{-1}\right)$ of the amphioxus, $C_{\mathrm{f}}$ is the metal concentration in the ingested algae $\left(\mu g^{-1}\right)$, and $k_{\text {ef }}$ is the efflux rate constant following uptake from food $\left(\mathrm{d}^{-1}\right)$.

Assuming that $C_{\mathrm{f}}$ can be predicted based on the bioconcentration factor of metals $\left(\mathrm{BCF}, \mathrm{l} \mathrm{kg}^{-1}\right.$, under equilibrium assumption) in the algae and $C_{\mathrm{w}}$, the fraction of metals accumulated from the dissolved phase ( $f$ ) can be calculated from the following equation:

$$
f=\left(k_{\mathrm{u}} / k_{\mathrm{ew}}\right) /\left(k_{\mathrm{u}} / k_{\mathrm{ew}}+\mathrm{AE} \times \mathrm{IR} \times \mathrm{BCF} / k_{\mathrm{ef}}\right)
$$

The trophic transfer factor (TTF) is the ratio of metal concentration in the amphioxus to metal concentration in the food, and can be calculated as (Wang \& Fisher 1999):

$$
\mathrm{TTF}=\mathrm{AE} \times \mathrm{IR} / k_{\mathrm{ef}}
$$

A TTF value $>1$ indicates a possibility of biomagnification, whereas a value $<1$ indicates that the metal is not biomagnified.

\section{Radioactivity measurements and statistical analysis}

Radioactivity was measured using a Wallac 1480 $\mathrm{NaI}$ (T1) gamma counter, at $88 \mathrm{keV}$ for $\mathrm{Cd}$ and $115 \mathrm{keV}$ for $\mathrm{Zn}$. Counting times were adjusted to yield a propagated counting error of $<5 \%$. All counts were corrected for radioactive decay and spillover. A 1 -way ANOVA was used to verify any significant difference $(p<0.05)$ by least significant difference (LSD) comparisons (SPSS 16.0 software).

\section{RESULTS}

\section{Waterborne uptake of $\mathrm{Cd}$ and $\mathrm{Zn}$}

The uptake of $\mathrm{Cd}$ and $\mathrm{Zn}$ from the dissolved phase increased linearly within the $9 \mathrm{~h}$ exposure period (Fig. 1). At the highest $\mathrm{Cd}$ and $\mathrm{Zn}$ concentrations, there was a rapid accumulation within the first $30 \mathrm{~min}$, which may have been due to the sorption of metals, followed by a linear pattern of accumulation. The calculated uptake rates also increased linearly with dissolved metal concentrations at a log-log scale (Fig. 1). The power coefficients for $\mathrm{Cd}$ and $\mathrm{Zn}$ were 0.763 and 0.713 , respectively, suggesting some degrees of metal regulation at a higher metal concentration, especially for Zn. We also regressed the metal uptake


Fig. 1. Branchiostoma belcheri. Accumulation of $\mathrm{Cd}$ and $\mathrm{Zn}$ in amphioxus during $9 \mathrm{~h}$ exposure and calculated influx rates $\left(I_{\mathrm{w}}\right)$ at different metal concentrations $\left(C_{\mathrm{w}}\right)$. Data are mean $\pm \mathrm{SD}(\mathrm{n}=6)$ 
rate and the dissolved metal concentration without any $\log -\log$ transformation. The slope of such a linear regression can be considered to be $k_{\mathrm{u}}$. Consequently, $k_{\mathrm{u}}$ was $0.107 \mathrm{l} \mathrm{g}^{-1} \mathrm{~d}^{-1}$ for $\mathrm{Cd}$ and $0.061 \mathrm{l} \mathrm{g}^{-1} \mathrm{~d}^{-1}$ for $\mathrm{Zn}$.

\section{Dietary assimilation of $\mathrm{Cd}$ and $\mathrm{Zn}$}

The percentage of $\mathrm{Cd}$ and $\mathrm{Zn}$ retained in the amphioxus following a pulse ingestion of different radiolabeled algae is shown in Fig. 2. The ingested food was rapidly lost within the first $9 \mathrm{~h}$ for all the diet treatments, followed by a relatively slower loss between 9 and $20 \mathrm{~h}$. After $20 \mathrm{~h}$ of depuration, there was no measurable radioactivity in the egested feces, suggesting that amphioxus completed their digestion and assimilation of the food materials within $20 \mathrm{~h}$. Correspondingly, the retention of $\mathrm{Cd}$ and $\mathrm{Zn}$ in the amphioxus was stable after $20 \mathrm{~h}$. The calculated AEs ranged from 7.6 to $34.3 \%$ for $\mathrm{Cd}$ and from 8.4 to $42.9 \%$ for $\mathrm{Zn}$ among the 5 diets (Table 1). The AEs of $\mathrm{Cd}$ and $\mathrm{Zn}$ for Chlorella autotrophica were the lowest

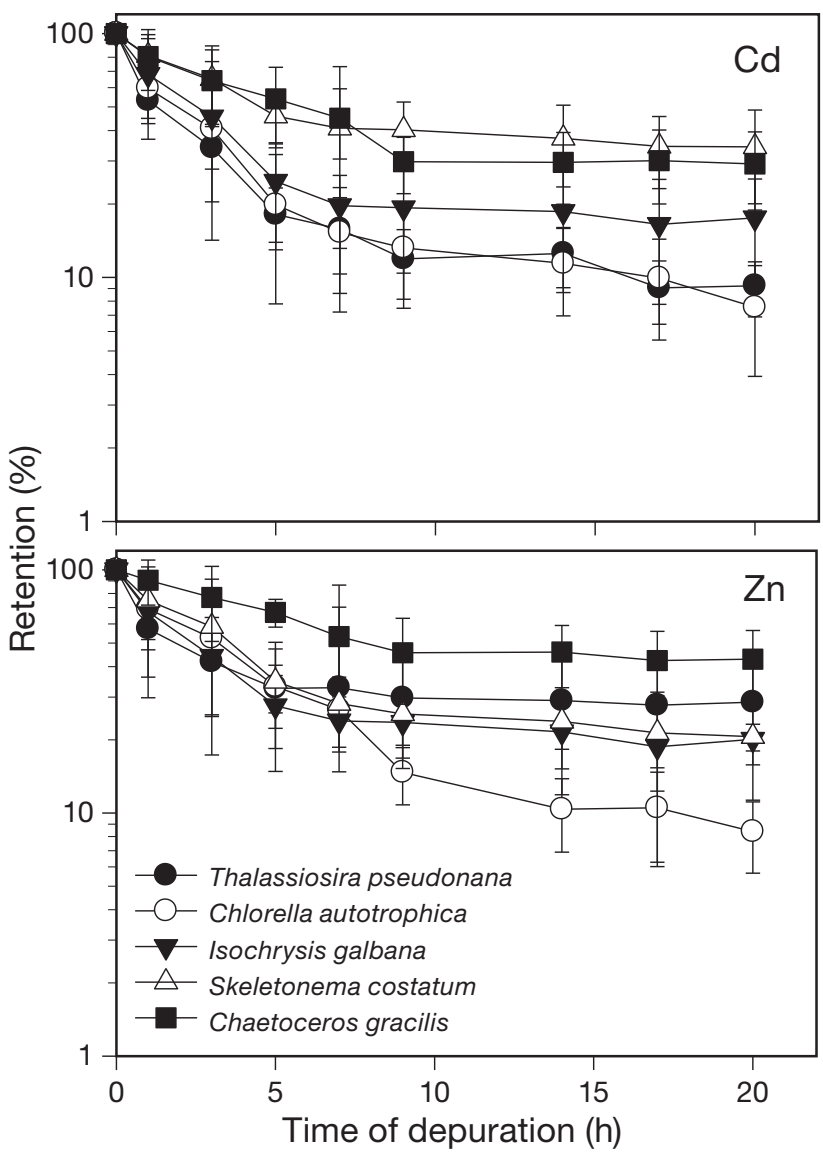

Fig. 2. Branchiostoma belcheri. Retention of $\mathrm{Cd}$ and $\mathrm{Zn}$ in amphioxus following pulse feeding on different radiolabeled algae. Data are mean $\pm \mathrm{SD}(\mathrm{n}=6)$
Table 1. Branchiostoma belcheri. Calculated dietary assimilation efficiencies (AEs) of $\mathrm{Cd}$ and $\mathrm{Zn}$ in amphioxus fed different algae $\left(1 \times 10^{5}\right.$ cells ml $\left.^{-1}\right)$ and different concentrations of Thalassiosira pseudonana. Data are mean \pm SD $(n=6)$. Different superscripted letters indicate significant difference at $p<0.05$ between the 2 treatments

\begin{tabular}{|lcc|}
\hline & Cd AE $(\%)$ & Zn AE $(\%)$ \\
\hline Chlorella autotrophica & $7.6 \pm 3.6^{\mathrm{a}}$ & $8.4 \pm 4.7^{\mathrm{a}}$ \\
T. pseudonana & $9.2 \pm 4.6^{\mathrm{a}}$ & $28.6 \pm 12.4^{\mathrm{ab}}$ \\
Isochrysis galbana & $17.5 \pm 7.8^{\mathrm{a}}$ & $20.1 \pm 9.7^{\mathrm{a}}$ \\
Skeletonema costatum & $34.3 \pm 16.1^{\mathrm{b}}$ & $22.9 \pm 8.6^{\mathrm{a}}$ \\
Chaetoceros gracilis & $29.1 \pm 11.3^{\mathrm{b}}$ & $42.9 \pm 14.6^{\mathrm{b}}$ \\
T. pseudonana & & \\
(cells ml $^{-1}$ ) 5 $510^{3}$ & $16.6 \pm 5.0$ & $46.9 \pm 6.3^{\mathrm{b}}$ \\
$2 \times 10^{4}$ & $9.7 \pm 3.2$ & $36.3 \pm 6.1^{\mathrm{ab}}$ \\
$1 \times 10^{5}$ & $9.1 \pm 4.4$ & $27.7 \pm 11.3^{\mathrm{a}}$ \\
$5 \times 10^{5}$ & $15.1 \pm 6.1$ & $36.2 \pm 11.4^{\mathrm{ab}}$ \\
\hline
\end{tabular}

among the 5 food types, whereas the highest $\mathrm{AE}$ for Cd was found for Skeletonema costatum (34\%), and for Zn for another diatom, Chaetoceros gracilis $(43 \%)$. Metal AEs differed significantly among the different algal diets $(\mathrm{p}<0.05)$.

Fig. 3 shows the percentage of $\mathrm{Cd}$ and $\mathrm{Zn}$ retained in the amphioxus fed different diatom Thalassiosira pseudonana concentrations. With increasing algal concentration from $5 \times 10^{3}$ to $1 \times 10^{5} \mathrm{cells} \mathrm{ml}^{-1}$, the calculated AEs of $\mathrm{Cd}$ and $\mathrm{Zn}$ in the amphioxus decreased from 16.6 to $9.1 \%$ and from 46.9 to $27.7 \%$ ( $<<0.05)$, respectively (Table 1). At the highest food concentration $\left(5 \times 10^{5} \mathrm{cells} \mathrm{ml}^{-1}\right)$, however, the AEs of $\mathrm{Cd}$ and $\mathrm{Zn}$ increased and were comparable to those determined at the lowest food concentration $\left(5 \times 10^{3}\right.$ cells $\mathrm{ml}^{-1}$ ). The calculated IR of amphioxus increased when the diatom concentration increased from $5 \times 10^{3}$ to $2 \times$ $10^{4}$ cells $\mathrm{ml}^{-1}(\mathrm{p}<0.01)$, and then decreased with a further increase in diatom concentration (Fig. 4).

\section{Efflux of Cd and Zn following waterborne and dietary exposure}

During the depuration period, the accumulated Cd following either waterborne or dietary exposure in amphioxus was lost gradually (Fig. 5). There was a 2-compartmental loss for $\mathrm{Cd}$ and $\mathrm{Zn}$ following both routes of exposure. At the end of depuration, there was no significant difference between the waterborne and dietary exposures in the percentage of $\mathrm{Zn}$ radioactivity retained in amphioxus (11.9\% for water exposure, and $9.9 \%$ for dietary exposure). However, the $\mathrm{Cd}$ retention in amphioxus after waterborne exposure $(53.0 \%)$ was significantly higher than that 


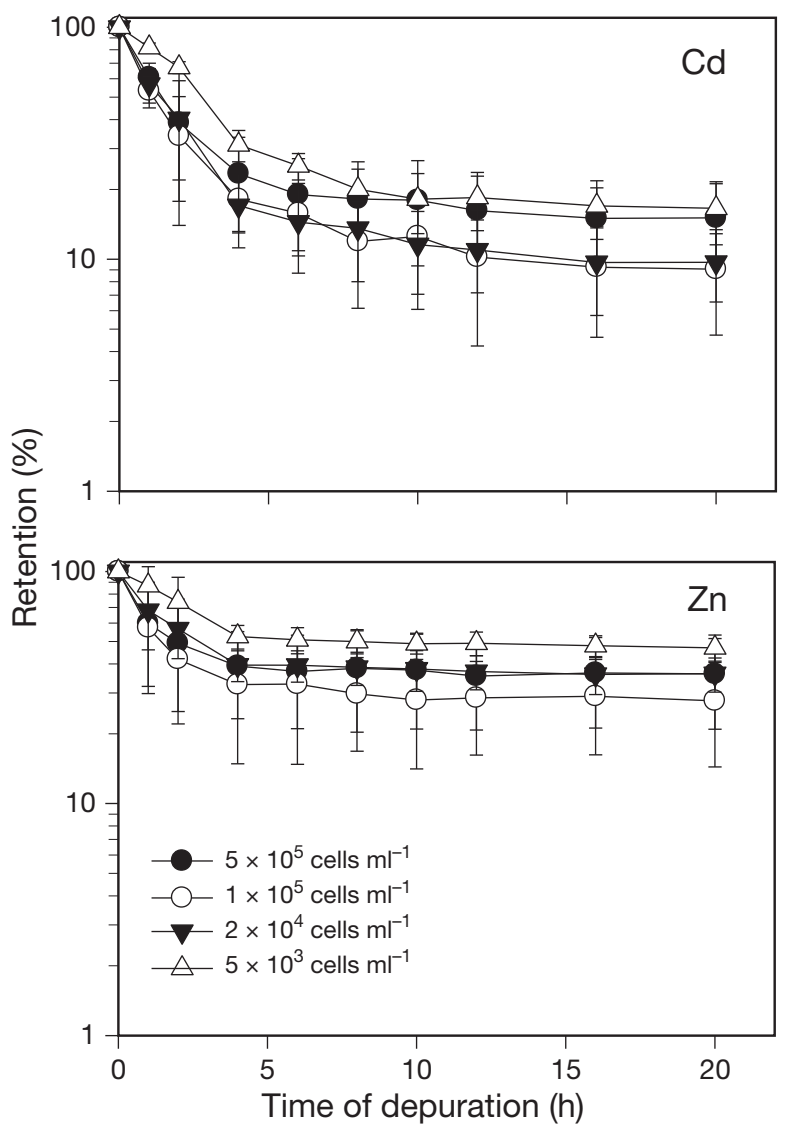

Fig. 3. Branchiostoma belcheri. Retention of $\mathrm{Cd}$ and $\mathrm{Zn}$ in amphioxus following pulse feeding on radiolabeled Thalassiosira pseudonana at different concentrations. Data are mean $\pm \operatorname{SD}(n=6)$

after dietary exposure $(27.2 \%)$. Accordingly, the $k_{\mathrm{e}}$ of Cd was nearly $3 \times$ higher following dietary exposure $\left(0.033 \mathrm{~d}^{-1}\right)$ than after waterborne exposure $(0.012$ $\left.\mathrm{d}^{-1}\right)$, and the $k_{\mathrm{e}}$ of $\mathrm{Zn}$ following dietary exposure $\left(0.040 \mathrm{~d}^{-1}\right)$ was comparable to that after waterborne exposure $\left(0.031 \mathrm{~d}^{-1}\right)$. The biological retention halflife of $\mathrm{Cd}$ and $\mathrm{Zn}$ in amphioxus was 57.8 and $22.4 \mathrm{~d}$ following waterborne exposure, and 21 and $17.3 \mathrm{~d}$ following dietary exposure, respectively.

\section{Modeling the importance of $\mathrm{Cd}$ and $\mathrm{Zn}$ uptake from water and food}

The relative importance of waterborne and dietary exposure to $\mathrm{Cd}$ and $\mathrm{Zn}$ in amphioxus can be calculated using Eq. (4) with the available biokinetic parameters. The $\mathrm{AE}, k_{\mathrm{u}}, k_{\mathrm{ew}}$, and $k_{\mathrm{ef}}$ of both $\mathrm{Cd}$ and $\mathrm{Zn}$ were all measured in this study (Table 2). The IR of amphioxus can be calculated from the known clearance rate (CR) and the total suspended loads (TSS) in

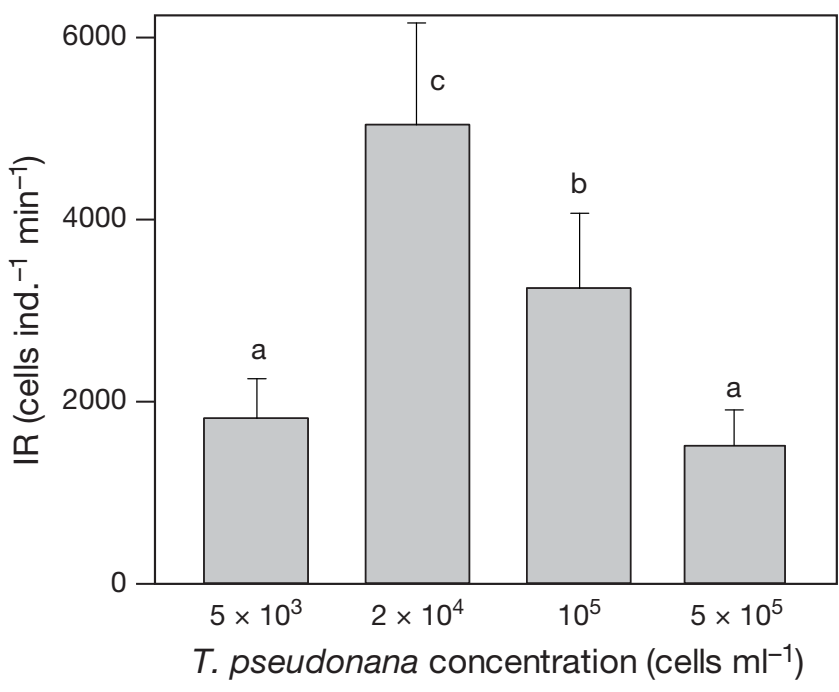

Fig. 4. Branchiostoma belcheri. Ingestion rates (IR) of amphioxus feeding on different concentrations of Thalassiosira pseudonana. Data are mean $\pm \mathrm{SD}(\mathrm{n}=6)$. Different letters indicate significant difference at $p<0.05$ between 2 treatments

the ambient environment. Previously, we quantified the CR of amphioxus under different food conditions (food species and food concentration), which ranged from 0.72 to $1.24 \mathrm{l} \mathrm{g}^{-1} \mathrm{~h}^{-1}$ (B. Lu et al. unpubl.). With an assumption of TSS in coastal waters of 0.5 to $5 \mathrm{mg}$ $\mathrm{l}^{-1}$ and that all these particles can be effectively ingested by the animals, the IR of Branchiostoma belcheri was calculated as $0.9 \sim 14.8 \%$ of the tissue dry weight per day. Similarly, the BCF of metals varied greatly under different environmental conditions and among different food species. A typical range of the $\mathrm{BCF}$ in algae was used in the modeling simulation $\left(\mathrm{Cd}: 10^{3} \sim 10^{4} \mathrm{l} \mathrm{kg}^{-1}\right.$, with a mean of $5 \times 10^{3} \mathrm{l} \mathrm{kg}^{-1}$; Zn: $5000 \sim 5 \times 10^{4} \mathrm{l} \mathrm{kg}^{-1}$, with a mean of $2 \times 10^{4} \mathrm{l} \mathrm{kg}^{-1}$; Wang \& Fisher 1999). The AEs of $\mathrm{Cd}$ and $\mathrm{Zn}$ in amphioxus were 7.6 to $34.3 \%$ and 8.4 to $42.9 \%$, respectively, and a mean value of $21 \%$ for $\mathrm{Cd}$ and $26 \%$ for $\mathrm{Zn}$ was used in the calculation.

Fig. 6 shows the predicted relative importance of dissolved uptake in amphioxus under different IRs and $\mathrm{BCFs}$, using the mean values of other biokinetic parameters from this study. Our calculations suggest that the contribution of dissolved uptake depended greatly on the changes in these parameters. It was however clear that under most circumstances, water uptake dominated (>50\%) the $\mathrm{Cd}$ bioaccumulation in the amphioxus. Using the median value of $\mathrm{BCF}$ (Table 2), we calculated that 65 to $97 \%$ of $\mathrm{Cd}$ was derived from waterborne exposure over the likely range of IR, highlighting the significance of this exposure route in $\mathrm{Cd}$ accumulation in amphioxus. 


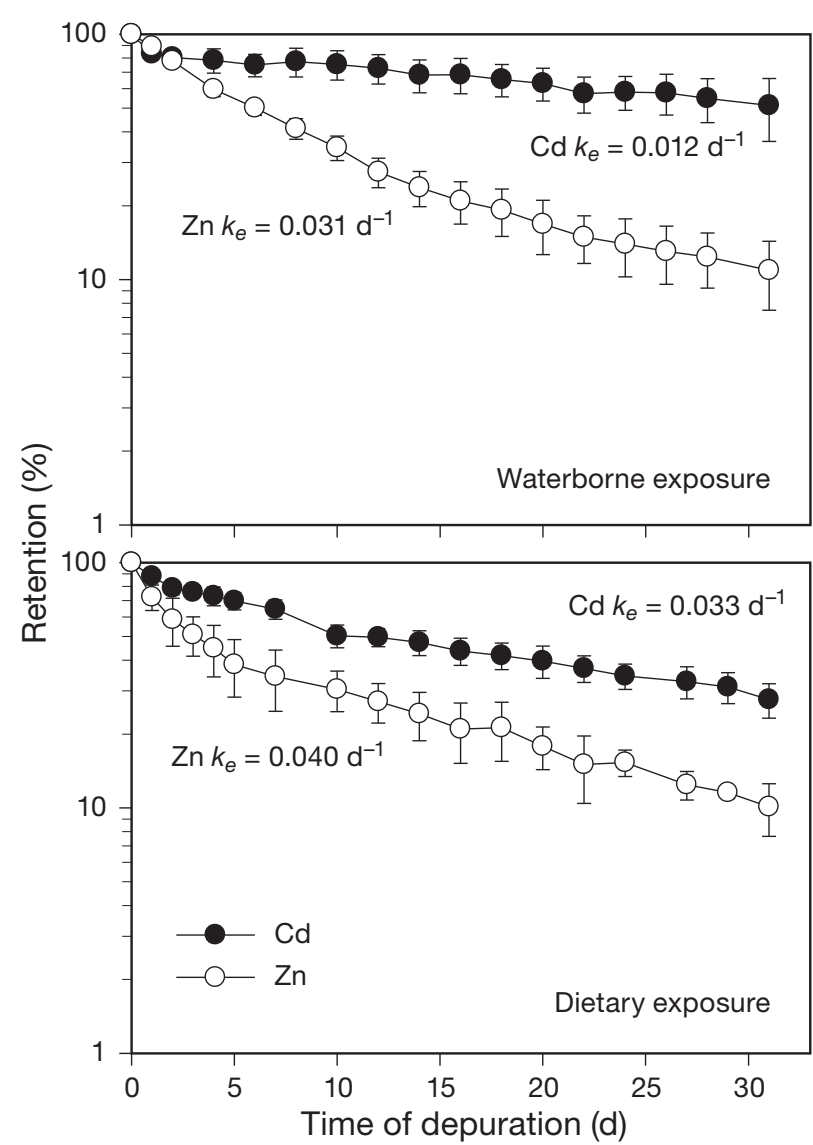

Fig. 5. Branchiostoma belcheri. Retention of $\mathrm{Cd}$ and $\mathrm{Zn}$ in amphioxus following $7 \mathrm{~d}$ of uptake from the dissolved phase and the dietary phase. $k_{\mathrm{e}}$ : calculated efflux rate constant. Data are mean \pm SD $(n=10)$

Table 2. Branchiostoma belcheri. Numeric values of biokinetic parameters of $\mathrm{Cd}$ and $\mathrm{Zn}$ used in modeling bioaccumulation of $\mathrm{Cd}$ and $\mathrm{Zn}$ in amphioxus

\begin{tabular}{|c|c|c|}
\hline Parameter & $\mathrm{Cd}$ & $\mathrm{Zn}$ \\
\hline $\begin{array}{l}\text { Dissolved uptake rate } \\
\text { constant }\left(k_{\mathrm{u}} 1 \mathrm{~g}^{-1} \mathrm{~d}^{-1}\right)\end{array}$ & 0.107 & 0.061 \\
\hline $\begin{array}{l}\text { Dietary assimilation } \\
\text { efficiency }(\mathrm{AE}, \%)\end{array}$ & $\begin{array}{c}8.0-34 \\
\text { (mean: 21) }\end{array}$ & $\begin{array}{c}8.0-43 \\
\text { (mean: 26) }\end{array}$ \\
\hline $\begin{array}{l}\text { Efflux rate constant after } \\
\text { dietary uptake }\left(k_{\mathrm{ef},} \mathrm{d}^{-1}\right)\end{array}$ & 0.033 & 0.040 \\
\hline $\begin{array}{l}\text { Efflux rate constant after } \\
\text { dissolved uptake }\left(k_{\mathrm{ew}} \mathrm{d}^{-1}\right)\end{array}$ & 0.012 & 0.031 \\
\hline Ingestion rate $\left(\mathrm{IR}, \mathrm{g} \mathrm{g}^{-1} \mathrm{~d}^{-1}\right)$ & $0.009-0.150$ & $0.009-0.150$ \\
\hline $\begin{array}{l}\text { Bioconcentration factor } \\
\left(\mathrm{BCF}, 1 \mathrm{~kg}^{-1}\right)\end{array}$ & $\begin{array}{c}10^{3}-10^{4} \\
\left(\text { mean: } 5 \times 10^{3}\right)\end{array}$ & $\begin{array}{l}5 \times 10^{3}-5 \times 10^{4} \\
\left(\text { mean: } 2 \times 10^{4}\right)\end{array}$ \\
\hline
\end{tabular}

For $\mathrm{Zn}$, the exposure route was highly dependent on the IR and BCF. At the lowest IR and Zn BCF, uptake from the dissolved phase contributed up to 9 to $63 \%$ of the total $\mathrm{Zn}$ in the amphioxus. Overall, both water-

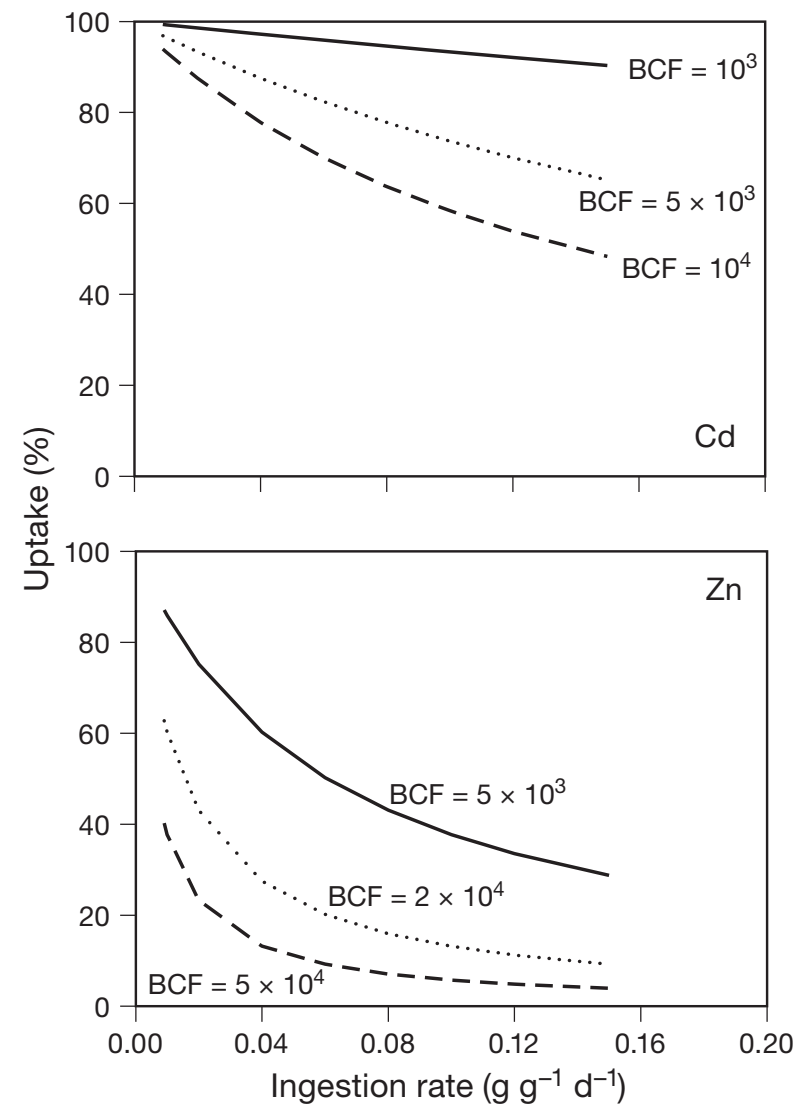

Fig. 6. Branchiostoma belcheri. Model prediction of relative importance of uptake from the dissolved phase of $\mathrm{Cd}$ and $\mathrm{Zn}$ in amphioxus as a function of the ingestion rate (IR). $\mathrm{BCF}$ : bioconcentration factor of metals in algae $\left(\mathrm{kg}^{-1}\right)$

borne and dietborne $\mathrm{Zn}$ contributed significantly to the total $\mathrm{Zn}$ accumulation in amphioxus.

We also calculated the likely TTF of $\mathrm{Cd}$ and $\mathrm{Zn}$ in amphioxus using Eq. (5) (Fig. 7). The TTFs for Cd and Zn were 0.02 to 1.54 and 0.02 to 1.61 , respectively. The predicted TTF was $<1$ under most conditions of IR and AE possibly encountered by the amphioxus. A TTF $>1$ was predicted only under the highest IR and AE. These calculations suggest that biomagnifications of both $\mathrm{Cd}$ and $\mathrm{Zn}$ were unlikely to occur in natural conditions.

\section{DISCUSSION}

\section{Waterborne uptake of $\mathrm{Cd}$ and $\mathrm{Zn}$}

The quantified $k_{\mathrm{u}}$ of $\mathrm{Cd}$ and $\mathrm{Zn}$ in amphioxus can be compared to those measured in other suspension feeders (e.g. marine bivalves and copepods) using similar experimental methodology. For example, the 


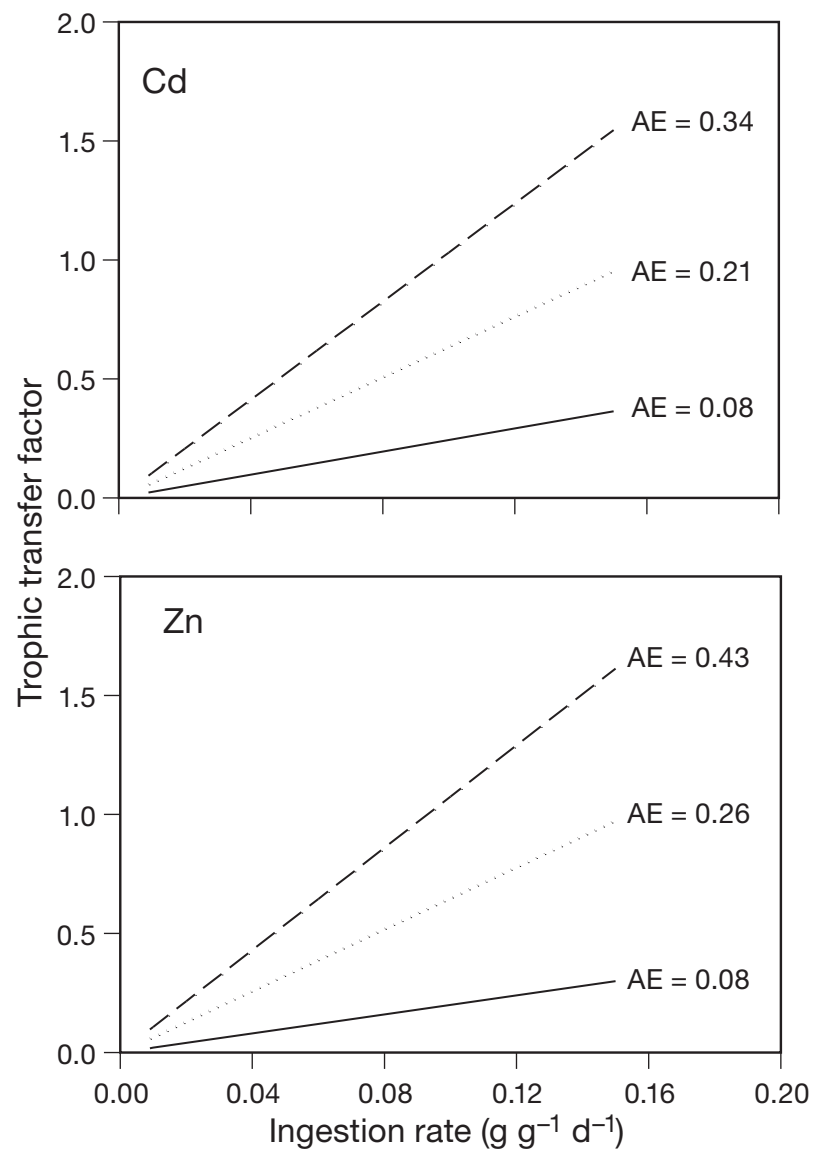

Fig. 7. Branchiostoma belcheri. Model prediction of trophic transfer factor of $\mathrm{Cd}$ and $\mathrm{Zn}$ in amphioxus as a function of ingestion rate. AE: dietary assimilation efficiency

$k_{\mathrm{u}}$ of $\mathrm{Cd}$ and $\mathrm{Zn}$ in the marine common mussel Mytilus edulis was 0.365 and $1.044 \mathrm{l} \mathrm{g}^{-1} \mathrm{~d}^{-1}$ (Wang et al. 1996, Wang 2003), and in the marine copepod Temora longicornis was 0.694 and $3.25 \mathrm{l} \mathrm{g}^{-1} \mathrm{~d}^{-1}$, respectively (Wang \& Fisher 1998). Wang (2001) found that the metal $k_{\mathrm{u}}$ was strongly related to the clearance rate of suspension feeders. For example, oysters generally had the highest clearance rate and correspondingly the highest $k_{\mathrm{u}}$ values among the different bivalve species examined (clams, oysters, mussels; Wang 2001). Thus, a more direct comparison of the metal uptake is the absorption efficiency of metals from the dissolved phase, which can be calculated as the uptake rate constant divided by the clearance rate of the animals. In our study, the clearance rate of amphioxus was estimated as 0.72 to $1.24 \mathrm{l} \mathrm{g}^{-1} \mathrm{~h}^{-1}$ (B. Lu et al. unpubl. data). Correspondingly, the calculated absorption efficiency of $\mathrm{Cd}$ and $\mathrm{Zn}$ in the amphioxus was 0.4 to $0.6 \%$ for $\mathrm{Cd}$ and 0.2 to $0.3 \%$ for $\mathrm{Zn}$, which was higher than those calculated from clams and black mussels for $\mathrm{Cd}(0.02$ to
$0.11 \%)$, but lower than those for Zn (0.38 to $0.51 \%$; Wang 2001).

Aqueous metal uptake by amphioxus was possibly through direct surface adsorption. The high uptake rate was related to the surface organizational structure of amphioxus. There are no shells or exoskeletons that could adsorb the metals on the surface of amphioxus. The epidermal cells of amphioxus are richly provided with microvilli, which generally consist of intense absorbing cells and allow the passage between the body lacunae and the environment (Olsson 1961). They can increase the surface area of amphioxus to volume ratio and lead to enhanced diffusion and transport. Thomas (1956) found that the amphioxus directly took up iodine through some epithelium cells of the ventral body wall from ambient water. Spencer \& Herskovic (1968) reported that after incubation of amphioxus in $10^{-5} \mathrm{M}$ beta-alanine-1 $-{ }^{14} \mathrm{C}$, radioactivity was detected in the exterior surface of amphioxus, with some radioactivity in the gut. Gosselck et al. (1978) also reported that amphioxus took up dissolved organic carbon through the epithelium.

\section{Assimilation of $\mathbf{C d}$ and $\mathrm{Zn}$}

The AEs of amphioxus for Cd and Zn were comparable to those found in other suspension feeders such as marine mussels. Typical AEs of $\mathrm{Cd}$ and $\mathrm{Zn}$ in Mytilus edulis ranged between 11 and $48 \%$, feeding on different algal foods (Wang \& Fisher 1996). Generally, food species can significantly affect metal AEs in marine invertebrates (Wang \& Fisher 1996, 1998, 1999, Chong \& Wang 2001). In earlier studies on marine mussels and clams (Wang \& Fisher 1996, Chong \& Wang 2000), it was also demonstrated that metals bound with Chlorella autotrophica were least assimilated, likely caused by the more rapid egestion of the green alga compared to other phytoplankton food. In the marine copepods Acartia tonsa and Temora longicornis, however, the AEs of metals were comparable among the different algal diets tested (Wang et al. 1996). Earlier studies suggested that metal distribution in algal cytoplasm and the gut passage time of metals were the 2 major determining factors in influencing dietary assimilation of metals in marine suspension feeders (Reinfelder \& Fisher 1991, Wang \& Fisher 1996).

Selectivity in the gut and differential egestion of unassimilated particles after ingestion may affect metal assimilation from particles entering the digestive tubules. As the ancestors of the earliest verte- 
brates, amphioxus has a simple tube of gut. The only alteration to this tube is a pouch, the diverticulum that branches off near the beginning of the tube. The walls of the tube and the diverticulum contain cells that secrete digestive enzymes into the lumen. The relatively stagnant materials in the diverticulum can be broken down by these enzymes. Absorption occurs by diffusion into the epithelial cells (Barrington 1937). In the AE experiment, we found that the amphioxus concentrated a large proportion of algal particles and then eliminated a significant amount of food particles during the first $2 \mathrm{~h}$ of depuration. These egested 'feces' were examined under the microscope and it was found that the algae were packaged in the mucus and were still alive and intact, indicating that algae were not actually digested. It thus appeared that the particles filtered by the amphioxus traveled quickly through the digestive tract by ciliary current and were mixed with the secretions to form the main food cord, and finally passed through the hind-gut and were driven out of the anus. Thus, only a small quantity of scattered particles stayed in the gut and were digested and absorbed.

In the present study, it appeared that the filter-feeding behavior in amphioxus was inhibited under high food concentration. Consistently, Azariah (1969a) found that a high density of food materials may induce the formation of mucous sheets, causing reduction of the gill slit area and the water current. Riisgard \& Svane (1999) reported that clearance of amphioxus Branchiostoma lanceolatum increased when algal concentration (Rhinomonas reticulate) increased from $10^{4}$ to $2.5 \times 10^{4} \mathrm{cells} \mathrm{ml}^{-1}$, but then decreased from 0.49 to $0.05 \mathrm{ml} \mathrm{min}^{-1}$ ind. $^{-1}$ when the algal concentration reached $7.3 \times 10^{4}$ cells ml $^{-1}$. It is clear that amphioxus have a mechanism to control the quantity of particles entering the incurrent stream of water using the oralhood cirri and the velar tentacles and velum (Barrington 1937). Rice (1880) suggested that periods of feeding may alternate during $B$. lanceolatum digestion, e.g. the animal may stop feeding when the gut is full with food materials. Such behavior may potentially affect the gut passage of food materials in amphioxus, and may explain the slight increase of metal assimilation at the highest food concentration tested.

\section{Efflux of Cd and Zn following waterborne and dietary exposure}

The present study provides the first quantitative estimates of efflux rates in amphioxus. Compared to other suspension feeders such as marine bivalves $\left(k_{\mathrm{e}}\right.$ for Cd: 0.010 to $0.020 \mathrm{~d}^{-1}$, and for Zn: 0.012 to 0.029 $\mathrm{d}^{-1}$ for mussels and clams; Wang 2003), the $k_{\mathrm{e}}$ of amphioxus were comparable or higher. However, the $k_{\mathrm{e}}$ of metals in marine copepods were about 5 to $10 \times$ higher, mainly due to their higher metabolism (Wang \& Fisher 1998).

Difference in $k_{\mathrm{e}}$ following aqueous and dietary exposures may have been due to the metals' different distributions within the amphioxus. For example, most $\mathrm{Cd}$ was distributed in the digestive tract following uptake from the dietary phase, but was evenly distributed in the body surface, coelom, and other tissues after aqueous exposure (data not shown). Similarly, Wang \& Fisher (1996) reported that Cd taken up by copepods from food was eliminated faster than that taken up from water. Waterborne metals tended to bind to chitinous exoskeletons to a much greater extent than metal accumulated from food, whereas dietborne metals were more enriched in the soft tissues of these animals. In contrast, Wang et al. (1996) found that the route of exposure did not significantly influence the $k_{\mathrm{e}}$ of $\mathrm{Cd}$ and $\mathrm{Zn}$ in Mytilus edulis.

\section{Modeling the importance of $\mathrm{Cd}$ and $\mathrm{Zn}$ uptake from water and food}

In the kinetic model, several key parameters affect the extent and route of metal accumulation. Our modeling results demonstrated that dissolved exposure was a major source of $\mathrm{Cd}$ bioaccumulation. The importance of waterborne uptake in amphioxus was primarily due to the rather high rate of dissolved uptake and a somewhat low IR. For suspension feeders such as mussels, their filtration and clearance rates were $2 \sim 3 \times$ higher than those in amphioxus (Riisgard \& Svane 1999, Wang 2001). For example, the IR was $0.27 \mathrm{~g} \mathrm{~g}^{-1} \mathrm{~d}^{-1}$ for Mytilus edulis and $0.42 \mathrm{~g}$ $\mathrm{g}^{-1} \mathrm{~d}^{-1}$ for Temora longicornis. It has been reported that amphioxus have adapted to a very low phytoplankon level (Riisgard \& Larsen 2000), and can regulate the volume of water filtered under the control of the nervous system when a large number of food particles in the surrounding water is available (Bone 1958, 1961, Azariah 1969b). For these animals, there was no necessity for a constant intake of fresh food material, and a single mass of food was sufficient for many hours (Barrington 1937). Such a manner of ingestion by amphioxus may lead to a low food supply and less significance of dietary exposure of metals.

The modeling results for $\mathrm{Cd}$ were, however, rather similar to those conducted for other suspension feed- 
ers such as marine bivalves and copepods. For example, in Mytilus edulis and Temora longicornis, $>50 \%$ of their $\mathrm{Cd}$ accumulation was likely contributed by dissolved uptake (Wang \& Fisher 1999). Under most conditions, Zn accumulation appeared to be dominated $(>50 \%)$ by dietary uptake in amphioxus. This is also consistent with modeling results in other suspension feeders such as mussels and copepods (Wang \& Fisher 1999, Chong \& Wang 2001). The difference between the relative importance of different exposure routes of $\mathrm{Cd}$ and $\mathrm{Zn}$ was probably due to the differences in the $\mathrm{BCF}$ and $k_{\mathrm{u}}$ between these 2 metals. $\mathrm{Cd}$ is generally considered less particlereactive than $\mathrm{Zn}$, and thus the relative distribution of $\mathrm{Cd}$ in the dissolved phase would be higher than that of $\mathrm{Zn}$.

The present study demonstrated that the dissolved uptake of $\mathrm{Cd}$ and $\mathrm{Zn}$ in amphioxus was comparable to those in marine bivalves, despite the fact that amphioxus only have non-respiratory gills. Such high absorption of metals may be primarily caused by amphioxus' very unique surface sorption of metals. The dietary AEs and efflux of $\mathrm{Cd}$ and $\mathrm{Zn}$ were also comparable to those determined in bivalves. The sorption of metals across the body surface may contribute to the importance of $\mathrm{Cd}$ dissolved uptake in the overall accumulation in the amphioxus. However, dietary exposure was more important than dissolved uptake for $\mathrm{Zn}$ under most environmental conditions, due to the higher particle reactivity of $\mathrm{Zn}$ compared with $\mathrm{Cd}$ and the relatively low dissolved uptake. Measurements of the biokinetics of metals can provide important information for understanding the exposure and bioaccumulation of metals in amphioxus. Given the dominance of $\mathrm{Cd}$ accumulation from the dissolved phase, waterborne exposure may be more realistic for toxicity testing. Nevertheless, dietary exposure and toxicity should certainly be considered in toxicity testing for $\mathrm{Zn}$.

Acknowledgements. We thank the 2 anonymous reviewers for their comments on this work. This study was supported by the Program for Changjiang Scholars and Innovative Research Team in University (PCSIRT, IRT0941), and by the General Research Funds from the Hong Kong Research Grants Council $(663009,662610)$ to W.X.W.

\section{LITERATURE CITED}

Azariah J (1969a) Studies on the cephalochordates of Madras coast: VI. Observation on the pharyngeal feeding mechanism in amphioxus Branchiostoma lanceolatum. Plant Sci 72:216-220
Azariah J (1969b) Studies on the cephalochordates of Madras coast. V. The effect of the concentration of particulate matter and the oxygen tension in sea-water on the filtration rates of amphioxus Branchiostoma lanceolatum. Proc Indian Acad Sci B 69:259-268

Barrington EJW (1937) The digestive system of amphioxus (Branchiostoma lanceolatus). Philos Trans R Soc Lond B 228:269-312

Bhattacharya H, Zhang S, Xiao Q (2008) Comparison of histopathological alterations due to sublethal $\mathrm{CCl}_{4}$ on rosy barb (Puntius conchonius) and amphioxus (Branchiostoma belcheri) with implications of liver ontogeny. Toxicol Mech Methods 18:627-633

Bone Q (1958) Nervous control of cilia in amphioxus (Branchiostoma). Nature 181:193-194

Bone Q (1961) The organization of the atrial nervous system of amphioxus (Branchiostoma lanceolatum (Pallas)). Philos Trans R Soc Lond B 243:241-269

Chen Y, Cheung SG, Shin PKS (2008) The diet of amphioxus in subtropical Hong Kong as indicated by fatty acid and stable isotopic analyses. J Mar Biol Assoc UK 88:1487-1491

Chong K, Wang WX (2000) Assimilation of Cd, Cr, and Zn by the green mussel Perna viridis and the clam Ruditapes philippinarum. Environ Toxicol Chem 19:1660-1667

Chong K, Wang WX (2001) Comparative studies on the biokinetics of $\mathrm{Cd}, \mathrm{Cr}$, and $\mathrm{Zn}$ in the green mussel Perna viridis and the Manila clam Ruditapes philippinarum. Environ Pollut 115:107-121

Evans DH, Piermarini PM, Choe KP (2005) The multifunctional fish gill: dominant site of gas exchange, osmoregulation, acid-base regulation, and excretion of nitrogenous waste. Physiol Rev 85:97-177

> Gosselck F, Keil V, Spittler P (1978) On the feeding of Branchiostoma senegalense (Acrania: Branchiostomidae). Mar Biol 46:175-179

- Holland LZ, Laudet V, Schubert M (2004) The chordate amphioxus: an emerging model organism for developmental biology. Cell Mol Life Sci 61:2290-2308

Light SF (1923) Amphioxus fisheries near the University of Amoy. Science 58:57-60

Nash TR, Ruppert EE, Colacino JM (2009) The absorption efficiency and respiration rate of the Florida Lancelet, Branchiostoma floridae. Comp Biochem Physiol A 154: 570-574

> Nielsen SE, Bone Q, Bond P, Harper G (2007) On particle filtration by amphioxus (Branchiostoma lanceolatum). J Mar Biol Assoc UK 87:983-989

> Olsson R (1961) The skin of amphioxus. Cell Tissue Res 54: 90-104

- Reinfelder JR, Fisher NS (1991) The assimilation of elements ingested by marine copepods. Science 251:794-796

Rice HJ (1880) Observations upon the habits, structure and development of Amphioxus lanceolatus. Am Nat 14:1-19

Riisgard HU, Larsen PS (2000) Comparative ecophysiology of active zoobenthic filter feeding, essence of current knowledge. J Sea Res 44:169-193

Riisgard HU, Svane I (1999) Filter feeding in lancelets (amphioxus), Branchiostoma lanceolatum. Invertebr Biol 118:423-432

> Ruppert EE, Nash TR, Smith AJ (2000) The size range of suspended particles trapped and ingested by the filterfeeding lancelet Branchiostoma floridae (Cephalochordata: Acrania). J Mar Biol Assoc UK 80:329-332

Schmitz A, Gemmel M, Perry SF (2000) Morphometric partitioning of respiratory surfaces in amphioxus (Branchio- 
stoma lanceolatum pallas). J Exp Biol 203:3381-3390

Spencer RP, Herskovic T (1968) $\beta$-alanine uptake by Amphioxus (Branchiostoma)-inhibition by furosemide. Biochem Pharmacol 17:2230-2231

Thomann RV (1981) Equilibrium model of fate of microcontaminants in diverse aquatic food chains. Can J Fish Aquat Sci 38:280-296

Thomas IM (1956) The accumulation of radioactive iodine by amphioxus. J Mar Biol Assoc UK 35:203-210

Wang WX (2001) Comparison of metal uptake rate and absorption efficiency in marine bivalves. Environ Toxicol Chem 20:1367-1373

Wang WX (2003) Metal bioaccumulation in bivalve mollusks: recent progress. In: Villalba A, Reguera B, Romalde JL, Beiras R (eds) Molluscan shellfish safety. Intergovernmental Oceanographic Commission of UNESCO and Conselleria de Pesca e Asuntos Maritimos da Xunta de Galicia, Santiago de Compostela, p 503-520

Wang WX (2011) Incorporating exposure into aquatic toxicological studies: an imperative. Aquat Toxicol 105 (Suppl):9-15

Wang WX, Fisher NS (1996) Assimilation of trace element and carbon by the mussel Mytilus edulis: effect of food

Editorial responsibility: Roderick Finn,

Bergen, Norway composition. Limnol Oceanogr 41:197-207

> Wang WX, Fisher NS (1997) Modeling metal bioavailability for marine mussels. Rev Environ Contam Toxicol 151: 39-65

> Wang WX, Fisher NS (1998) Accumulation of trace elements in a marine copepod. Limnol Oceanogr 43:273-283

> Wang WX, Fisher NS (1999) Delineating metal accumulation pathways for marine invertebrates. Sci Total Environ 237/238:459-472

> Wang WX, Rainbow PS (2008) Comparative approaches to understand metal bioaccumulation in aquatic animals. Comp Biochem Physiol C 148:315-323

Wang WX, Fisher NS, Luoma SN (1996) Kinetic determinations of trace element bioaccumulation in the mussel Mytilus edulis. Mar Ecol Prog Ser 140:91-113

Wu XH, Jiang XJ, Zhang BL, Qu YM (1999) Toxic effects of several heavy metals on amphioxus and living activity of Branchiostoma belcheri. Oceanol Limnol Sin 30: 604-608

Zhang QJ, Zhong J, Fang SH, Wang YQ (2006) Branchiostoma japonicum and $B$. belcheri are distinct lancelets (Cephalochordata) in Xiamen waters in China. Zool Sci 23:573-579

Submitted: March 8, 2012; Accepted: May 24, 2012

Proofs received from author(s): July 18, 2012 